\title{
Benchmark Concentration: Capitalization Weights Versus Equal Weights in the FTSE 100 Index
}

\author{
Isaac T. Tabner \\ University of Stirling, U.K.
}

Identifying a suitable benchmark is essential when testing asset pricing models, measuring the performance of active investors, or providing market proxy portfolios for passive investors. Concern that increased domination of capitalization weighted stock indices by a few large firms will lead to inefficient portfolio diversification is leading some investors and researchers to argue that index providers should adjust their weighting methods to limit concentration. This study tests and rejects the hypothesis that concentration arising as a result of capitalization weights in the FTSE 100 Index increases risk, either during normal market conditions or during negative tail events in the return distribution. On the contrary, during the left tail of the return distribution, the equally weighted portfolio of FTSE 100 Index constituents exhibits higher risk and lower returns than the capitalization weighted FTSE 100 Index portfolio, a finding consistent with variations of the CAPM that allow for time varying risk premia.(JEL: G11, G12, G14)

Keywords: stock index benchmarks, incremental returns, incremental standard deviation, portfolio diversification, capitalization weights, index concentration, performance measurement.

\section{Introduction}

Stock Indices are used as benchmarks for testing asset pricing models

\footnotetext{
* The author would like to thank the University of Stirling for funding this research, anonymous reviewers for providing valuable feedback, the participants at the European Winter Finance Summit in Helmsedal, March 2006, the participants and the discussant, Paulo Armada Leite, at the Multinational Finance Society Conference in Edinburgh in June 2006. Particular thanks are also due to Chris Brooks, Kevin Campbell, Alan Goodacre, Rezaul Kabir and Chris Veld for their ongoing support and advice. The author retains responsibility for any errors.
}

(Multinational Finance Journal, 2009, vol. 13, no. 3/4, pp. 209-228)

(C) Multinational Finance Society, a nonprofit corporation. All rights reserved. DOI: $10.17578 / 13-3 / 4-3$ 
and by investors to gauge the performance of the market. They are also important as model portfolios for passive investors and as benchmarks against which the added value or alpha of active investors can be measured. The characteristics of a good benchmark portfolio are defined comprehensively by Bailey (1992). These include the requirement to be transparent, unambiguous, easy to replicate and measurable. However, Ranaldo and Haberle (2008) argue that many supposedly passive benchmark portfolios represented by major indices, such as the S\&P 500 and FTSE 100, actually have more in common with an actively managed portfolio than a passive benchmark, or proxy for their respective sections of the market portfolio.

According to the Capital Asset Pricing Model (CAPM) capitalization weights provide the most theoretically appealing method for calculating market benchmark indices. This is because investors are assumed to create mean variance efficient portfolios based upon their expectations about returns, variance and covariance. Hence, in an efficient market, capitalization weights of the market index represent the average of investors' attempts to capture the benefits of modern portfolio theory (MPT) as defined by Markowitz (1952). In fact, according to the CAPM, an equally weighted index, or indeed any non capitalization weighted index, should be less efficient and hence, have lower risk adjusted returns. Although studies such as Fama and French (1993), Carhart (1997) and others pose a challenge to the traditional CAPM, later extensions to the CAPM, such as the scaled consumption ratio (C)CAPM, of Lettau and Ludvigson (2001), which allows for time varying market risk premia, address much of that challenge. Likewise, it is often observed that the equally weighted market index of the Chicago Centre for Research in Security Prices (CRSP) outperforms the capitalization weighted CRSP index. Yet, as early as 1982, this out-performance was demonstrated to be unstable if the $\beta$ coefficient of the CAPM regression was allowed to vary stochastically through time (Ohlson and Rosenberg 1982). Indeed the sign of the intercept was found to be dependent upon the stochastic model specified for the $\beta$ coefficient (Ohlson \& Rosenberg 1982). Notwithstanding the theoretical underpinning for capitalization weighted indices, high levels of firm and industry level concentration in major market indices, such as the FTSE 100 Index and the Nasdaq Composite, have led some to question the merits of capitalization weighting. For example, Arnott, $\mathrm{Xu}$ and Moore (2005 p. 93) express concerns to the effect that “...through the 1962-2004 period; we experienced bubbles in which cap weighting caused severe destruction of investor wealth..." 
Instead of capitalization weights, Arnott, Xu, and Moore (2005) propose a fundamental weighting system based on variables such as the net earnings, number of employees and total sales of index constituent firms. Capitalization weights have also caused problems for institutional investors that face regulatory limits on the proportion of assets invested in any one firm. An issue that prompted FTSE International to prepare an alternative version of the FTSE 100 and FTSE Allshare Index in which constituent weights are capped at 5\% to, "allow for a more diversified index", while Merrill Lynch Investment Management created an equally weighted version of the FTSE 100 as a benchmark because, it "should show lower volatility, thanks to better diversification" (Financial Times 2000).

Much of the concern voiced about stock market, and index, concentration stems from the naive diversification principles of Evans and Archer (1968), namely that investors should spread their portfolio between eight to ten randomly selected firms to reduce stock specific risk. A study by Bloomfield, Leftwich, and Long (1977) raised the number to around twenty firms. This then increased to between fifty and one hundred (Campbell et al. 2001), and to more than three hundred (Statman 2004). Kryzanowski and Singh (2006) find that the minimum number of firms needed to reduce most of the stock specific risk in a portfolio is higher for the Canadian equity market than for the US equity market. They suggest that the difference is due to the presence of a greater number of imperfectly correlated industries in the US market; thereby highlighting the importance of covariance, rather than firm numbers, in determining the structure of an efficiently diversified portfolio.

Proposals for capped weights, equal weights, or fundamental weights seem to be a direct challenge to the theoretical arguments supporting the CAPM and the Efficient Markets Hypothesis (EMH). Furthermore, non capitalization weighted indices are less likely to meet the criteria of a suitable benchmark, as defined by Bailey et al. (1992) or Ranaldo and Haberle (2008). For instance, the greater frequency of re-balancing required to maintain capped or equal weights will result in higher portfolio transaction costs, thus reducing their investability.

Compared to capitalization weighted benchmarks, returns of an equally weighted benchmark are likely to be influenced more by smaller firms. Therefore, counter to the theoretical principles of the CAPM, empirical evidence for the small firm effect supports the prediction that broad benchmark indices with capped or equal weights are likely to have higher market risk adjusted returns than capitalization weighted 
TABLE 1. Concentration Of The Top Ten Firms And Industries In The FTSE 100 Index In January 1984 And January 2005

A. Top 10 Firms and Industries in the FTSE 100 Index in January 2005

\begin{tabular}{|c|c|c|c|c|c|}
\hline Firm Name & Weight & $\begin{array}{c}\text { Cumulative } \\
\text { weight }\end{array}$ & Industry & Weight & $\begin{array}{c}\text { Cumulative } \\
\text { weight }\end{array}$ \\
\hline $\mathrm{BP}$ & $10 \%$ & $10 \%$ & Banks & $23 \%$ & $23 \%$ \\
\hline HSBC Holdings & $8 \%$ & $18 \%$ & Oil integrated & $15 \%$ & $37 \%$ \\
\hline Vodafone Group & $7 \%$ & $25 \%$ & Pharmaceuticals & $9 \%$ & $47 \%$ \\
\hline Glaxosmithkline & $6 \%$ & $31 \%$ & Telephone wireless & $8 \%$ & $55 \%$ \\
\hline Royal Bankof Scotland & $5 \%$ & $36 \%$ & Mining & $5 \%$ & $60 \%$ \\
\hline $\begin{array}{l}\text { Shell Transport } \\
\text { and Trading. }\end{array}$ & $4 \%$ & $40 \%$ & Food retailers & $3 \%$ & $63 \%$ \\
\hline Barclays & $3 \%$ & $43 \%$ & Food producers & $3 \%$ & $65 \%$ \\
\hline Astrazeneca & $3 \%$ & $46 \%$ & $\begin{array}{l}\text { Tobacco } \\
\text { Distilleries }\end{array}$ & $3 \%$ & $68 \%$ \\
\hline HBOS & $3 \%$ & $49 \%$ & $\begin{array}{l}\text { and Vintners } \\
\text { Retailers and }\end{array}$ & $2 \%$ & $70 \%$ \\
\hline Lloyds TSB Group & $2 \%$ & $51 \%$ & department stores & $2 \%$ & $72 \%$ \\
\hline
\end{tabular}

B. Top 10 Firms and Industries in the FTSE 100 Index at Base January 1984

\begin{tabular}{|c|c|c|c|c|c|}
\hline Firm Name & Weight & $\begin{array}{c}\text { Cumulative } \\
\text { weight }\end{array}$ & Industry & Weight & $\begin{array}{c}\text { Cumulative } \\
\text { weight }\end{array}$ \\
\hline $\begin{array}{l}\text { British Petroleum } \\
\text { Shell Transport }\end{array}$ & $7 \%$ & $7 \%$ & Speciality chemicals & $10 \%$ & $10 \%$ \\
\hline $\begin{array}{l}\text { And Trading. } \\
\text { GEC }\end{array}$ & $6 \%$ & $14 \%$ & $\begin{array}{l}\text { Food retailers } \\
\text { Diversified }\end{array}$ & $8 \%$ & $18 \%$ \\
\hline $\begin{array}{l}\text { (now Marconi) } \\
\text { Imperial Chemical }\end{array}$ & $5 \%$ & $19 \%$ & industrials & $8 \%$ & $25 \%$ \\
\hline $\begin{array}{l}\text { Industries } \\
\text { Marks And }\end{array}$ & $4 \%$ & $23 \%$ & Banks & $6 \%$ & $32 \%$ \\
\hline $\begin{array}{l}\text { Spencer } \\
\text { British American }\end{array}$ & $3 \%$ & $25 \%$ & Food producers & $6 \%$ & $38 \%$ \\
\hline Tobacco & $3 \%$ & $28 \%$ & Insurance brokers & $6 \%$ & $44 \%$ \\
\hline Glaxo Holdings & $3 \%$ & $31 \%$ & Life insurance & $4 \%$ & $49 \%$ \\
\hline BTR & $2 \%$ & $33 \%$ & Tobacco & $4 \%$ & $53 \%$ \\
\hline $\begin{array}{l}\text { Beecham Group } \\
\text { Grand }\end{array}$ & $2 \%$ & $35 \%$ & Auto parts & $3 \%$ & $55 \%$ \\
\hline Metropolitan & $2 \%$ & $37 \%$ & Builders' merchants & $3 \%$ & $58 \%$ \\
\hline
\end{tabular}

Note: Source: Thomson Financial Datastream. Firms and industries are listed in decreasing order of weight. Industry identifies the Thomson Financial Datastream level six industry sub-group mnemonic.

portfolios of the same constituents. However, indices such as the FTSE 100 are restricted to large firms and their constituents often account for 
TABLE 2. Concentration Of The Top Ten And Top Decile Firms And Industries By Capitalization In A Global, Regional And Selected National Market Indices: January 2005

\begin{tabular}{|c|c|c|c|c|}
\hline $\begin{array}{l}\text { Country/ } \\
\text { Region }\end{array}$ & Index name & $\begin{array}{l}\text { Proportion } \\
\text { of value in } \\
\text { top ten } \\
\text { firms }\end{array}$ & $\begin{array}{l}\text { Proportion } \\
\text { of value in } \\
\text { top decile } \\
\text { of firms }\end{array}$ & $\begin{array}{l}\text { Proportion } \\
\text { of value in } \\
\text { top ten } \\
\text { industries }\end{array}$ \\
\hline World & Dow Jones FTSE Global 100 & $88 \%$ & $88 \%$ & $98 \%$ \\
\hline Europe & Dow Jones FTSE Eurotop 100 & $35 \%$ & $35 \%$ & $83 \%$ \\
\hline US & Russell 1,000 & $19 \%$ & $57 \%$ & $43 \%$ \\
\hline US & S\&P 100 & $40 \%$ & $40 \%$ & $43 \%$ \\
\hline US & Nasdaq Composite & $28 \%$ & $61 \%$ & $63 \%$ \\
\hline US & Nasdaq 100 & $55 \%$ & $55 \%$ & $87 \%$ \\
\hline Japan & Topix 1,000 & $19 \%$ & $58 \%$ & $49 \%$ \\
\hline Japan & Topix 100 & $34 \%$ & $34 \%$ & $64 \%$ \\
\hline UK & UK Equity Market & $40 \%$ & $83 \% *$ & $59 \%$ \\
\hline UK & FTSE 100 & $51 \%$ & $51 \%$ & $72 \%$ \\
\hline
\end{tabular}

Note: Source: Thomson Financial Datastream and for the UK Equity Market the London Stock Exchange Files of Listed Firms. Industries refer to Thomson Financial Datastream Level Six Industry Sub-Groups. *The UK equity market includes the ordinary shares of 990 firms listed on the UK main market with an equity value of greater than $£ 1 \mathrm{~m}$ after excluding firms listed on the alternative investment market (AIM) and closed ended investment companies.

less than $10 \%$ of the total number of firms listed on their respective exchanges. Hence, even allowing for the possibility that the small firm effect cannot be explained by CAPM variations incorporating time varying risk premia, time varying $\beta$ coefficients or, the small firm effect should still not be a factor driving the returns of an equally weighted constituent portfolio of a large firm index.

Although large firm indices have a relatively small number of constituents, compared to the total listed, they usually account for considerably more than $50 \%$ of the capitalization of their respective markets. Thus the constituents of large firm indices are more liquid, more investable and, arguably, more economically relevant than those of small firm indices. Nonetheless, within many large firm indices, the degree of concentration is such that considerable variation in relative firm size exists between constituents. For example, on the $31^{\text {st }}$ December 2004, the largest firm in the FTSE 100 Index, BP, was one hundred and twenty-three times larger than the smallest, Antofagasta. Tables 1 and 2 provide more general evidence related to this point. The objective of this study, is to investigate whether concentration in a large firm index such as the FTSE 100, does indeed increase risk without 
increasing returns, as suggested by authors such as Arnott, $\mathrm{Xu}$, and Moore (2005) and some professional investors, or whether on the contrary, a concentrated capitalization weighted index actually outperforms the non concentrated equally weighted index, as implied by the CAPM and similar models.

\section{Derivation and Selection of the Data Sample}

This study focuses on a large firm index, the FTSE 100, thereby eliminating the confounding effect of a potential small firm premium. It empirically investigates whether the equally weighted portfolio of FTSE 100 Index constituents underperforms the capitalization weighted FTSE 100 Index as suggested by the CAPM, after accounting for the market risk factor implicit in the capitalization weighted FTSE 100 Index returns. Furthermore, it examines the sensitivity of an equally weighted portfolio of FTSE 100 Index constituents to the capitalization weighted FTSE 100 Index during the lower tail of the FTSE 100 Index return distribution and during the upper tail of the earnings yield of the FTSE 100 Index, the upper tail of the term premium of ten year government bonds over three month treasury bills and the upper tail of the default premium of benchmark corporate bond yields over ten year government bond yields.

In a time series study of stock index concentration it is necessary to measure the weights of constituent firms in order to measure the concentration of an index portfolio. Therefore, the choice of index is limited by the availability of data identifying not only current constituents but historic index constituents and the original base constituents. These conditions are necessary in order to allow recreation of the historic index portfolio enabling historic levels of concentration to be evaluated using financial databases, such as Thomson Financial Datastream. As a capitalization weighted index of the 100 largest firms listed on the London Stock Exchange, the FTSE 100 Index meets all of the above criteria. Unlike more comprehensive market Indices, such as the FTSE All Share Index, the original constituent list together with the names and dates of subsequent additions and deletions are publicly available from inception in January 1984 through to the present. In addition, the constituent selection procedures and calculation methods are more transparent than those of competing index providers. Furthermore, the concentration of the FTSE 100 Index increased, and by some measures doubled, over the last ten years, to the extent that at 
the time of writing more than $50 \%$ of the index value is accounted for by the ten largest firms. These characteristics combined with the depth and liquidity of the constituents, and size of the London Stock Exchange as a whole, justify the selection of the FTSE 100 for this study.

The FTSE 100 constituent list is updated quarterly based on the capitalization ranking of firms with a primary listing on the UK market. However, constituent changes may take place within quarters if mergers, de-listings, or new listings, result in potential constituents being deleted or created. Further details are provided in the "Guide to Calculation Methods for the UK Series of the FTSE Actuaries Share Indices". From September $20^{\text {th }} 2000$, FTSE International began to phase in a free float adjusted weighting method. The analysis presented here is based upon a recreation of the Index using the original weighting method until the $20^{\text {th }}$ September 2000 and the free float adjusted method post September 2000. Analysis was also performed using unadjusted weights throughout; however, the results were not materially different from those presented here because firms with the greatest weight in the index had a free float of $100 \%$.

\section{A. Concentration}

A key feature of the analysis is the idea that an index of concentration or diversity can be used to measure the distribution of constituent weights within a stock index portfolio. Based on the analysis of a range of different concentration metrics by Clarke (1993), the Hirschman Herfindahl Index $(H)$ of concentration and the variance of the logarithm of firm size are calculated using the equity market values of FTSE 100 constituents.

Values of the $H$ index are calculated at twenty trading day intervals as follows:

$$
H_{1}=\sum_{i=1}^{N}\left(x_{i} / x\right)^{2}=\sum_{i=1}^{N} w_{i}^{2}
$$

where $w_{i}$ is the weight of an individual company in a sample, $x_{i}$ is the value of firm $i$ and $x$ is the total value of all $N$ firms. The $H$ index is influenced more by the biggest firms in a portfolio as it is the sum of the squared weights of all the portfolio firms. $H$ has an upper limit of unity in the hypothetical scenario in which the entire market is represented by just one firm. It has a minimum value of $1 / N \rightarrow 0$ in the case of many small equally sized firms. 
In the situation where firm values have an approximately log normal distribution, the variance of the logarithm of firm weights $\left(V^{2}\right)$ provides an unambiguous ranking of firm size inequality (Clarke 1993). The distribution of FTSE 100 Index constituent firm size and firm weights was found to be approximately log-normal; therefore, daily values of the variance of the logarithms of firm weights sampled at twenty trading day intervals are calculated as follows:

$$
V^{2}=\frac{1}{N} \sum_{i=1}^{N}\left[\log \left(w_{i} / w_{g}\right)\right]^{2}
$$

where $\bar{w}_{g}$ is equal to the geometric mean of firm weights.

A range of other concentration metrics were also calculated for the FTSE 100 Index constituents. However, the time series path of many of these appeared very similar to the $H$ index, which is influenced relatively more by large firms. An exception is the $V^{2}$ index that is influenced by a more even range of firm sizes in the distribution. Therefore, the decision was made to report only the $H$ index and the $V^{2}$ index. The latter adds value to the analysis by confirming that concentration has increased over time, regardless of which part of the firm size distribution is emphasised.

\section{B. Capitalization Weighted FTSE 100 Index and Equally Weighted Constituent Portfolio Returns}

The Datastream Total Return Index and market value data for all FTSE 100 Index constituents past and present are used to calculate the dividend-inclusive geometric returns for the FTSE 100 Index constituents over the entire study period. Geometric equally weighted and capitalization weighted returns are used to calculate FTSE 100 Index portfolio returns and the returns of the equally weighted portfolio of constituents. However, once the cross section of constituent returns is aggregated to form the respective index, or portfolio, they are then converted to logarithmic returns for time series analysis. The incremental return is defined as the capitalization weighted return minus the equally weighted return.

\section{Incremental Standard Deviation}

Non-overlapping monthly data for the realised capitalization weighted 
and equally weighted monthly variance are derived by taking the sum of squared daily value and equally weighted returns over twenty trading days. The assumption of an expected return of zero for estimating realised volatility was proposed by Figlewski (1997) and has been adopted more recently by Goyal and Santa-Clara (2003). When equity returns are measured at daily frequencies, or less, a mean return of zero is a reasonable assumption, given that the realised variance over periods of up to one month is large in relation to estimates of the mean return. The square roots of each variance series then proxy as the realised capitalization and equally weighted monthly standard deviations. The incremental standard deviation is defined as the capitalization weighted standard deviation minus the equally weighted standard deviation.

\section{Results and Analysis of the Data}

\section{A. Concentration in the FTSE 100 Index}

Figure 1, plots the levels of both the Hirschman-Herfindahl Index and the Variance of the Logarithm of Firm Size. From 1997 onwards, concentration increased rapidly, reaching current levels around March 2000 when there was a structural break resulting from the Vodafone-Mannessmann merger event, after which concentration levels remained high until the end of the study period.

Figure 2, indicates that relatively low levels of concentration observable in figure 1 during the early to the mid 1990s correspond with the fall in the number of mergers and an increase in the number of divestitures. The rapid increase in concentration in the late 1990s coincided with an increase in the value of both domestic and foreign mergers. Throughout the 1980s, both before and after the 1987 crash, the number and value of mergers between UK firms increased to a peak in 1989. However, figure 2 also reveals that the recession of the early 1990s was characterised by a fall in the number of mergers and an increase in the number of divestitures resulting in a trend towards more 'focussed' firms. Unlike earlier merger waves aimed at the formation of conglomerates, many of the mergers in the 1990s resulted in the creation of multinational firms via horizontal mergers within the same industry. Pharmaceuticals, telecommunications, software development and oil production were notable examples of consolidating industries in this period. The increased importance of international mergers is evident from the greater percentage of the total value of mergers accounted for 


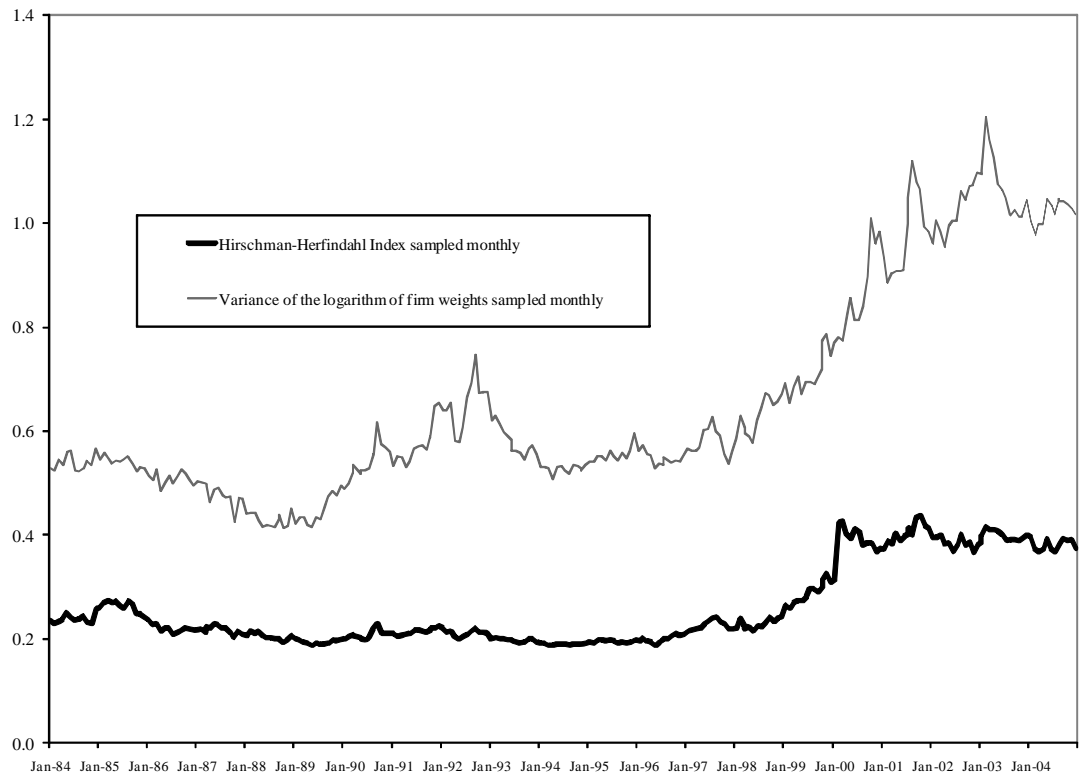

Month \& Year

FIGURE 1.- Level concentration metrics (scaled)

Note: The level concentration metrics, sampled at twenty trading day intervals, are plotted over the entire study period. In order to fit the two series onto the same chart, the Hirschman-Herfindahl Index has been scaled up by a factor of ten, while the variance of the logarithm of firm weights remains unchanged.

by foreign firms through much of the 1990s, apart from the dips in 1995 and 1996, which are followed by a rise to the peak in 1999. Examples include the merger of BP with Amoco Oil, Vodafone with Mannesmann and Glaxo-Welcome with Smith-Kline and Beecham to form Glaxo-Smithkline. These firms have expanded overseas to such an extent that the majority of their revenues are now generated outside of the UK. In fact, Orton (2001) cites Michael Hughes of Baring Asset Management

"More than half of the constituents of the FTSE 100 Index,.....now derive the majority of their earnings from international activities."

Examination of the financial statements of the larger index constituent firms provides plenty of supporting evidence for the above statement. Thus, while there are over seven hundred firms listed on the main section of the London market, excluding closed ended investment companies, the majority of the equity market capitalization is accounted for by fewer than twenty large global industry leaders. 


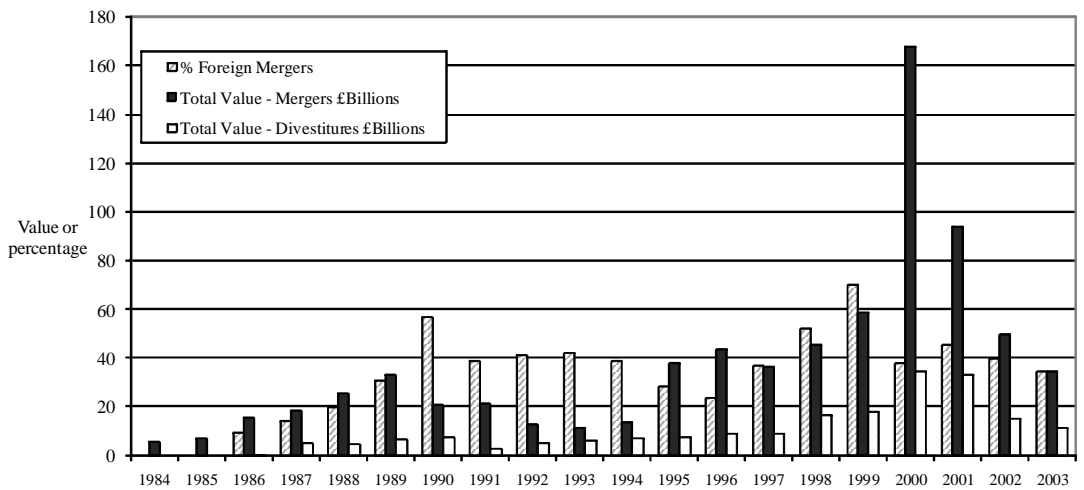

FIGURE 2.- Value of mergers and divestitures involving UK firms

Note: Source: Office for National Statistics data. Note: total value includes mergers between UK and foreign and UK and UK firms. The \% foreign refers to the proportion of UK firms acquired by, or merging with, foreign firms.

\section{B. Descriptive Statistics of the Data Series}

Incremental returns and standard deviations arise as a result of concentration of capitalization weights in the index. Positive incremental returns indicate that the capitalization weighted FTSE 100 Index portfolio return is greater than the equally weighted portfolio of constituents, while negative values of the incremental standard deviation indicate that the capitalization weighted portfolio returns are less variable than their equally weighted counterparts.

Panel A. of table 3, reports the descriptive statistics for the annualised discrete non-overlapping sequences of monthly return and volatility data. It is immediately apparent that none of the data series conform to the characteristics of a normal distribution because they all exhibit skewness and kurtosis values outside the defining range of the Jarque-Bera test. Although the mean and median standard deviation is higher in the capitalization weighed index than in the equally weighted portfolio, both the maximum and minimum values of the standard deviations are lower, as are the skewness and kurtosis, indicating that during conditions of market stress, the variability of the capitalization weighted portfolio increases by less than that of the equally weighted portfolio. At 0.1 and 0.2 standard deviations from zero, respectively, the annualised mean and median of the incremental standard deviation indicates that for the majority of the time, the capitalization weighted FTSE 100 Index portfolio is not significantly more risky than the equally weighted portfolio. 


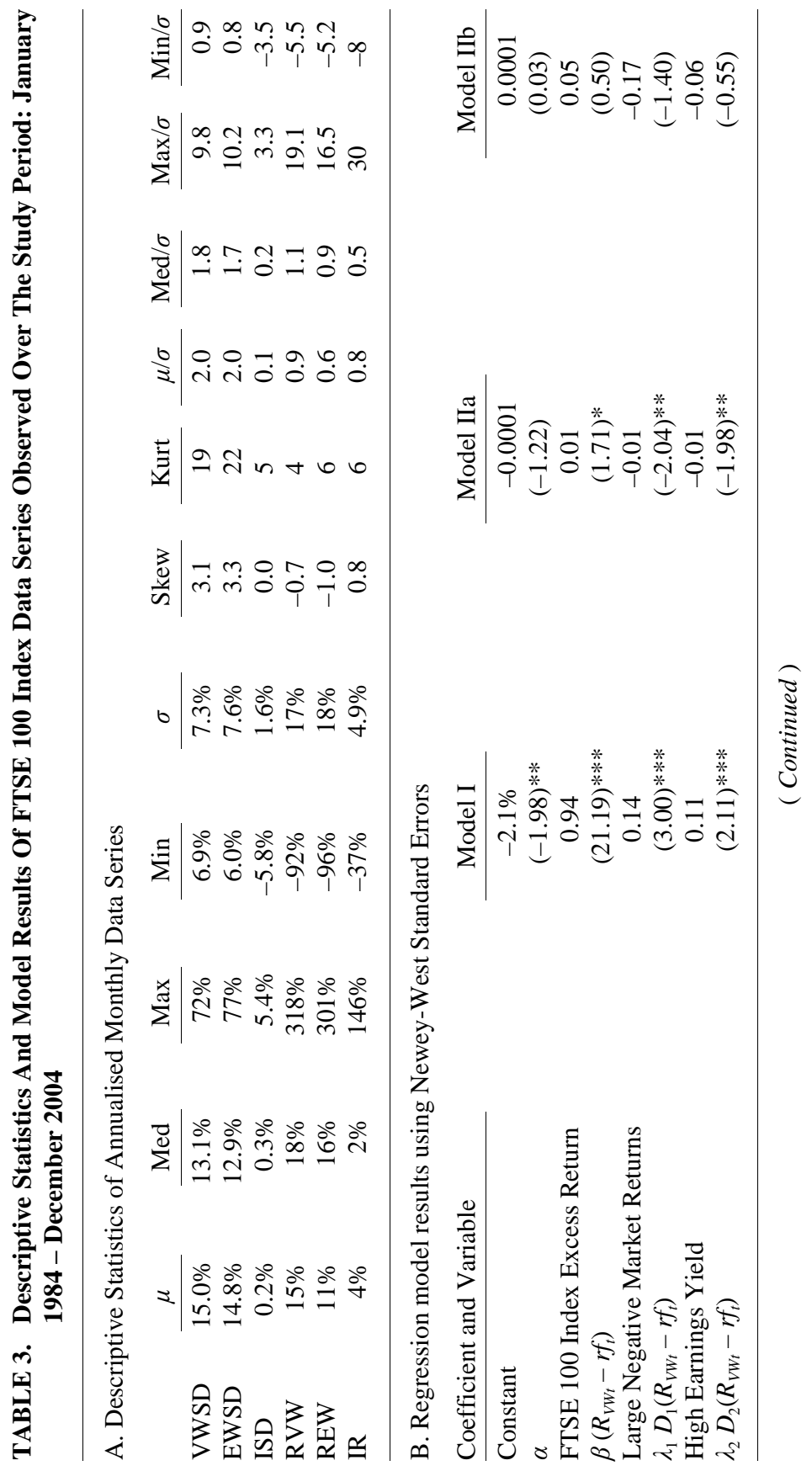




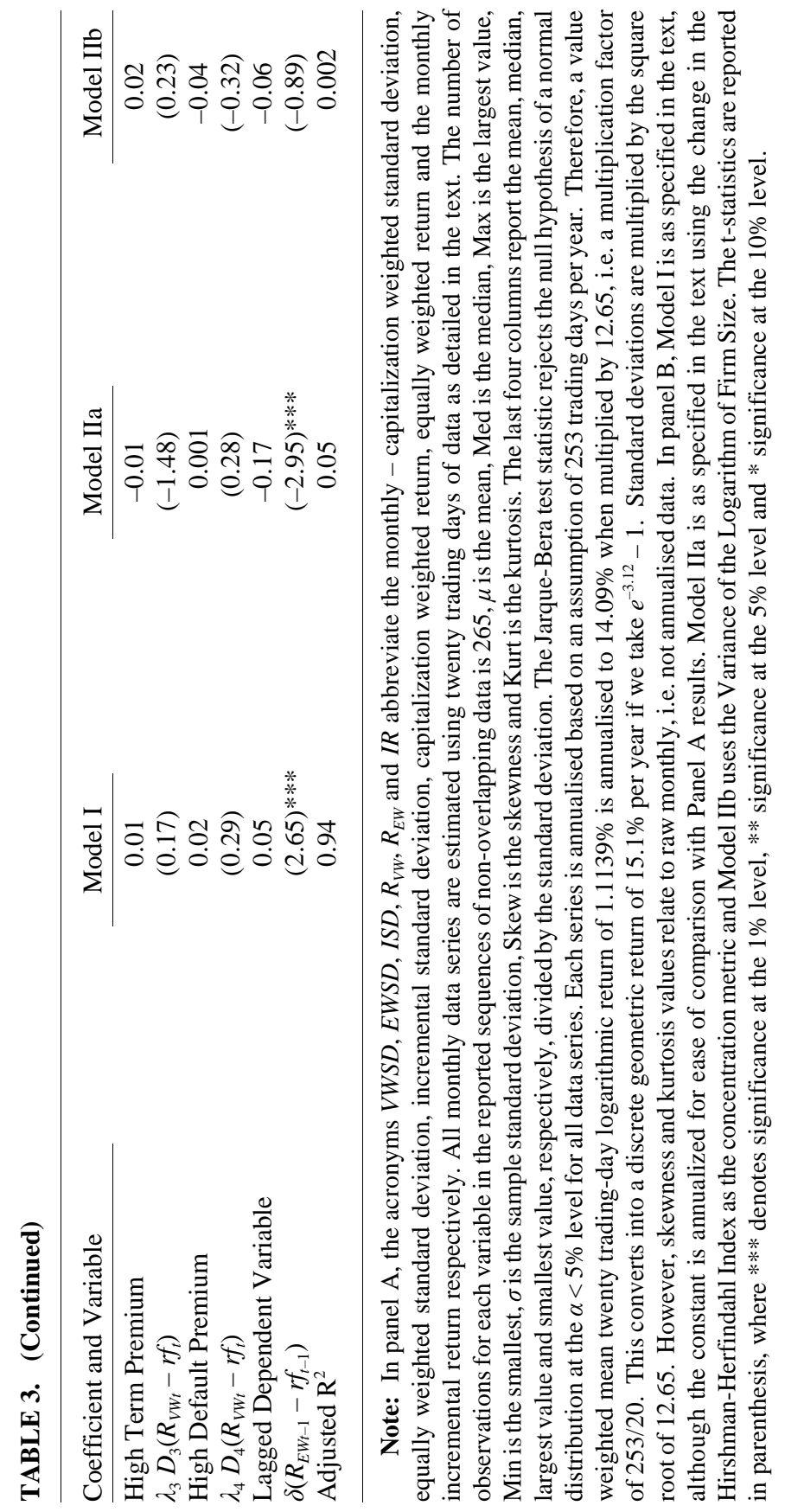


Both the mean and the median annualised incremental returns are positive at $4 \%$ and $2 \%$ respectively. The maximum value is an annualised contribution of $146 \%$ to total portfolio return, while the minimum is $-37 \%$. This is 30 and 8 standard deviations away from zero respectively. This is significant at a level of $a<1 \%$ under most known probability distributions and under Chebyshev's inequality. Taken together with the positive skewness this indicates that during extreme market conditions, the contribution of the incremental return to the total FTSE 100 Index returns are larger during positive extremes than they are during negative extremes. These findings imply that very large firms with a greater weight in the index have higher returns on average than the smaller firms and that their returns are less volatile during periods of market crisis. The lower volatility is not entirely surprising given that many large firms are multinationals with more diverse revenue streams than their smaller counterparts. It should be noted that smaller firms in the FTSE 100 Index are still large firms when compared to the market as a whole and that for much of the 1990s large growth firms out-performed small value firms reversing the small firm value premium documented in many studies published during the late 1980s and early 1990s (Dimson, Nagel, and Quigley 2003).

\section{Implications for Asset Pricing Theories}

A capitalization weighted index would be expected to perform better during market downturns than an equally weighted index if it is assumed that large firms have lower systematic risk than smaller firms. Furthermore, if investors' marginal utility increases during economic contractions, the required return will increase on all risky assets and prices will fall to reflect the new equilibrium discount rate. However, the discount rate on riskier assets with high market $\beta$ coefficients will increase by more than the required return on less risky assets. Therefore, the prices of the high $\beta$ stocks will fall further than those with a lower $\beta$ and further than would be implied by their $\beta$ for a similar market fall if the risk premium had remained unchanged. The result is that the observed systematic risk of stocks with a $\beta$ greater than unity appears to be time varying and increasing when market returns are negative. ${ }^{1}$ An alternative explanation with similar results is to allow for the possibility of time varying market risk, as identified empirically by Schwert (1989) and other studies. In this case, during times of greater uncertainty,

1. A proof is available from the author on request. 
investors will require higher returns in order to compensate them for the greater levels of risk. As security prices collectively fall to reflect the new equilibrium rate of return the observed correlations between individual security returns will appear to rise, as will their average $\beta$ coefficients with the market return, also giving the impression that the $\beta$ coefficients of individual securities are time varying.

Model I aims to test the hypothesis that the sensitivity of the equally weighted returns to the capitalization weighted returns increases during bad times. Such a finding would be expected if marginal utility increases during bad times, or if market risk increases during bad times. Thus model I formally tests the relationships between equally weighted portfolio returns and the value weighted FTSE 100 Index portfolio that are indicated by descriptive statistics of the raw unconditional data presented in panel A of table 3.

Even if the risk premium is constant, during periods of declining or negative expected growth in corporate profitability, stock prices will fall relative to current profits and the trailing earnings yield will rise, reflecting the increase in the applied discount rate as the growth rate in the denominator of the present value equation turns negative. Likewise, term premiums are expected to be positive when the economic outlook is improving, because future interest rates are more likely to rise than to fall, although during times of extreme market crisis this may be reversed as investors try to exit less liquid assets in favour of cash. Default premiums are higher during economic downturns to reflect the increased probability of bankruptcy and default. Hence for the purpose of model I higher than usual market $\beta$ coefficients are expected to coincide with below average equity market returns, above average trailing market earnings yields, below average term premiums and above average default premiums.

\section{Model I specification}

$$
\begin{gathered}
R_{E W t}-r f_{t}=\alpha+\beta\left(R_{V W_{t}}-r f_{t}\right)+\lambda_{1} D_{1}\left(R_{V W_{t}}-r f_{t}\right)+\lambda_{2} D_{2}\left(R_{V W_{t}}-r f_{t}\right)+ \\
\lambda_{3} D_{3}\left(R_{V W_{t}}-r f_{t}\right)+\lambda_{4} D_{4}\left(R_{V W_{t}}-r f_{t}\right)+\delta\left(R_{E W t-1}-r f_{t-1}\right)+\varepsilon_{t}
\end{gathered}
$$

$R_{E W t}$ is the return of the equally weighted portfolio of FTSE 100 Index constituents during month $t, r f_{t}$ is the return on one-month UK treasury-bills during month $t$ (Thomson Financial Datastream code LDNTB1M), $\lambda_{1}$ to $\lambda_{4}$ are interaction coefficients with $\beta$ and the interaction dummies $D_{1}$ to $D_{4}$. $D_{1}$ is an interaction dummy variable equal 
to unity in months when the capitalization weighted FTSE 100 Index experienced a total excess return over one-month treasury bills of 0.85 standard deviations or more below the mean observed during the study period. If the return distribution is normal this would approximate to the bottom quintile of monthly returns. $D_{2}$ is an interaction dummy variable equal to unity when the trailing earnings yield on the FTSE 100 Index (calculated by taking the reciprocal of the FTSE100 Index PE ratio) is more than 0.85 standard deviations above the mean value observed during the study period. $D_{3}$ is an interaction dummy variable equal to unity when the term premium, of the ten year Benchmark Government Bond yield (Thomson Financial Datastream code UKMGLTB) above the one month UK Treasury-Bill yield, is more than 0.85 standard deviations above the average observed during the study period. $D_{4}$ is an interaction dummy variable equal to unity when the default premium, of the Benchmark UK Corporate Bond yield (Thomson Financial Datastream code UKMCRPB) above the ten-year Benchmark Government Bond yield, is more than 0.85 standard deviations above the average default premium observed during the study period. The model results did in fact seem largely insensitive to the choice of cutoff point for the three dummy variables with ranges between 0 and 3 standard deviations tested. Furthermore, alternative model specifications using the raw earnings yield, term and default premiums were also tried without materially affecting the results from those reported. Correlations between dummy variables are negligible, unlike between alternative valuation ratios such as earnings yield, dividend yield and book to market ratio, hence the decision to use only one valuation ratio (Earnings Yield) in the reported model results.

\section{E. Model I Hypotheses}

\section{$H 1$ - Relative Returns of the Equally Weighted Versus Value Weighted Portfolio}

According to the CAPM and the EMH, a market proxy portfolio that is equally weighted, or constructed using any non capitalization based weighting scheme, will have inferior risk adjusted returns compared to the capitalization weighted equivalent. Hence, as model I aims to explain the relationship between the returns of a non-capitalization weighted portfolio with the capitalization weighted FTSE 100 Index portfolio, the intercept coefficient $\alpha$ is expected to be negative and statistically significant, as it is reported in panel B of table 3 .

The small firm effect widely documented by empirical studies is not 
explained by the CAPM. The results reported here appear more consistent with the CAPM than with the small firm effect. However, even if we allow for the existence of the small firm effect, the results are still not surprising given that although the FTSE 100 Index accounts for more than $80 \%$ of the UK market by capitalization, it accounts for less than $20 \%$ of the total number of firms listed on the Main Market of London Stock Exchange, meaning that it is essentially a portfolio of the largest and most liquid firms.

H2 - Average $\beta$ Coefficients of Portfolio Constituents to the Market Risk Factor

According to the traditional CAPM, individual security returns are linearly related to market returns and the average $\beta$ coefficient across all securities to the market, or the market proxy portfolio will not be significantly different from unity, as is indicated by the empirically estimated coefficient $\beta$ reported for model I in panel B of table 3, during normal market conditions.

In addition to assuming a linear relationship between individual security returns and the market returns, the traditional CAPM assumes that market risk and the market risk premium is constant. If this is true, there should be no interaction between the sign of market returns, earnings yield, term premium, default premium and the $\beta$ coefficient in model I. However, although the coefficients $\lambda_{3}$ and $\lambda_{4}$ on the interaction dummies $D_{3}$ and $D_{4}$ are reported in panel B of table 3 as not significantly different from zero, the coefficients $\lambda_{1}$ and $\lambda_{2}$ on interaction dummies $D_{1}$ and $D_{2}$ are positive and significantly different from zero, implying that in the bottom quintile of market monthly returns, and the top quintile of monthly trailing earnings yield, the $\beta$ slope coefficient increases above unity when it is added to the interaction dummy coefficients $\lambda_{1}$ and $\lambda_{2}$.

The positive interaction dummy coefficients $\lambda_{1}$ and $\lambda_{2}$ suggest that during market downturns, the covariance of less large stocks with the returns of the capitalization weighted portfolio increases. Hence the $\beta$ coefficient with the market portfolio is close to unity during normal market conditions but exceeds unity during times of market stress. This implies that the equally weighted portfolio is riskier than the capitalization weighted portfolio and is likely to suffer larger negative returns during periods of market stress. The findings are consistent with other studies which allow for a time varying risk premium or a time varying $\beta$ coefficients, such as Lettau and Ludvigson (2001) and Ohlson and Rosenberg (1982) respectively. 
Model II repeats the process carried out by model I for the relationship between changes in concentration and the FTSE 100 index returns.

\section{F. Model II specification}

$$
\begin{gathered}
\Delta C_{t}=\alpha+\beta\left(R_{V W_{t}}-r f_{t}\right)+\lambda_{1} D_{1}\left(R_{V W_{t}}-r f_{t}\right)+\lambda_{2} D_{2}\left(R_{V W_{t}}-r f_{t}\right)+ \\
\lambda_{3} D_{3}\left(R_{V W_{t}}-r f_{t}\right)+\lambda_{4} D_{4}\left(R_{V W_{t}}-r f_{t}\right)+\delta \Delta C_{t-1}+\varepsilon_{t}
\end{gathered}
$$

In model II, $\Delta C_{t}$ is the change in concentration at time $t$, defined as the differenced Hirschman-Herfindahl Index in model IIa and the differenced Variance of the Logarithm of Firm Size in model IIb, other variables are as for model I.

\section{G. Model II hypotheses}

\section{H3 - Firm size and concentration}

If small firms have higher market $\beta$ coefficients than large firms, their stock prices will fall further than large firms and index concentration will increase during times of market stress. By contrast, under normal market conditions, it is difficult to anticipate what effect, if any, changes in market returns will have on index concentration. The results of model IIa presented in panel B of table 3, document a positive empirical association between market returns and changes in concentration during normal market conditions which is significant at the $\alpha<10 \%$ level. However, the $\lambda_{1}$ and $\lambda_{2}$ coefficients on the interaction dummy variables for the left tail of market returns and the right tail of earnings yield are negative and significant at the $\alpha<5 \%$ level indicating that smaller firms do indeed fall in value relative to large firms during periods of market stress, although the interpretation of these results should be tempered by the equivalent non significant coefficients observed for model IIb which uses the Variance of the logarithm of firm size as the concentration metric.

\section{Concluding Comments}

Although some argue that capitalization weighted indices could be more risky when concentration levels rise, a fall in risk is also consistent with 
the principles of modern portfolio theory. For example, conglomerate firms are portfolios of subsidiaries whose investment returns may not be perfectly correlated. Therefore, it is theoretically possible for all the firms in the market portfolio to merge into one. If such a hypothetical situation existed in an efficient market, the optimal mean variance efficient portfolio would contain the stock of the single firm that would, by definition, represent the market index portfolio. ${ }^{2}$ Without going to such hypothetical extremes, it can be argued that large multinational 'mega' firms in a concentrated stock index, such as the FTSE 100 may represent a diverse collection of income streams that have a low correlation with each other and with other large firms in the index.

The findings of this study demonstrate that investors in the FTSE 100 Index are concentrating more of their assets into fewer firms than they were twenty years ago. However, by concentrating their assets into just a few large firms investors do not appear to have increased the risk of their portfolios during down markets. On the contrary, the risk adjusted return of the equally weighted portfolio is lower than that of the capitalization weighted portfolio. In fact, the $\beta$ sensitivity of the equally weighted portfolio to the capitalization weighted market proxy portfolio increases during conditions of market stress in a manner consistent with variations of the CAPM which allow for time varying risk premia or time varying $\beta$ coefficients. Hence security market $\beta$ coefficients estimated from regression models during periods that are predominantly good for equity markets may understate the true market risk that would be experienced in bad times. This study also explicitly tests and finds in favor of the hypothesis that concentration at the firm level increases during negative tail events in the return distribution, providing further evidence in support of the premise that smaller firms decrease in value by more than large firms during periods of market stress.

Accepted by: Prof. R. Taffler, Guest Editor, February 2009

Prof. P. Theodossiou, Editor-in-Chief, February 2009

\section{References}

Arnott, R. D.; Hsu, J.; and Moore, P. 2005. Fundamental indexation. Financial Analysts Journal 60 (March/April): 83-99.

Bailey, J.V. 1992. Evaluating benchmark quality. Financial Analysts Journal 48 (May/June): 33-39.

Bloomfield, T.; Leftwich R.; and Long, J. 1977. Portfolio strategies and

2. The author is indebted to an anonymous reviewer for suggesting this analogy. 
performance. Journal of Financial Economics 5 (November): 201-218.

Campbell, J. Y.; Lettau, M.; Malkiel, B.G.; and Xu, Y. 2001. Have individual stocks become more volatile? An empirical exploration of idiosyncratic risk. Journal of Finance 56 (February): 1-43.

Carhart, M. M. 1997. On persistence in mutual fund performance. Journal of Finance 52 (March): 57-82.

Clarke, R. 1993. Industrial Economics. Cambridge Massachusetts: Blackwell.

Dimson, E.; Nagel, S.; and Quigley, G. 2003. Capturing the value premium in the United Kingdom. Financial Analysts Journal 59 (November/ December): 35-44.

Evans, J. L., and Archer, S.H. 1968. Diversification and the reduction of dispersion: an empirical analysis. Journal of Finance 23 (December): 761-767.

Fama, E. F., and French, K.R. 1993. Common risk factors in the returns on stocks and bonds. Journal of Financial Economics 33 (February): 3-56.

Figlewski, S. 1997. Forecasting volatility. Financial Markets, Institutions and Instruments Salomon Centre.: New York University. 6 (February): 1-88.

Financial Times, 2000. Weights lifted off fund managers' shoulders. Financial Times Euro Markets Section November 29th.

Goyal, A., and Santa-Clara, P. 2003. Idiosyncratic risk matters! Journal of Finance 58 (June): 975-1007.

Kryzanowski, L., and Singh, S. 2006. Should minimum portfolio sizes be prescribed for achieving sufficiently well-diversified equity portfolios? Working Paper (November): 2006.

Lettau, M., and Ludvigson, S. 2001. Resurrecting the (C)CAPM: a Cross-sectional test when risk premia are time varying. The Journal of Political Economy 109 (December): 1238-1287.

Longin, F., and Solnik, B. 2001. Extreme correlation of international equity markets. Journal of Finance 56 (April): 649-676.

Markowitz, H. M. 1952. Portfolio selection. Journal of Finance 7 (March): 77-91.

Ohlson, J., and Rosenberg, B. 1982. Systematic risk of the CRSP Equal-Weighted Common Stock Index: a History estimated by stochastic-parameter regression. The Journal of Business 55 (October): 121-145.

Orton, I. 2001. A small world may be a riskier home. Financial Times February 24th.

Ranaldo, A., and Haberle, R. 2008. Wolfe in sheep's clothing: the active investment strategies behind index performance. European Financial Management 14 (January): 55-81.

Schwert, W. G. 1989. Why does stock market volatility change over time? Journal of Finance 44 (December): 1115-1153.

Statman, M. 2004. The diversification puzzle. Financial Analysts Journal 60 (July/August): 44-53. 